\title{
Phenol degradation by Acinetobacter sp. in the presence of heavy metals
}

\author{
S.A. Ahmad ${ }^{*}$, N.A. Shamaan ${ }^{2}$, M.A. Syed ${ }^{1}$, F.A. Dahalan ${ }^{3}$, K. Abdul Khalil ${ }^{4}$, N.A. Ab Rahman ${ }^{1}$ and \\ M.Y. Shukor ${ }^{1}$ \\ ${ }^{I}$ Department of Biochemistry, Faculty of Biotechnology and Biomolecular Sciences, Universiti Putra Malaysia, Selangor, Malaysia. \\ ${ }^{2}$ Faculty of Medicine and Health Sciences, Universiti Sains Islam Malaysia, Kuala Lumpur, Malaysia. \\ ${ }^{3}$ The School of Environmental Engineering, Universiti Malaysia Perlis, Perlis, Malaysia. \\ ${ }^{4}$ Biomolecular Science Program, School of Biology, Faculty of Applied Sciences, Universiti Teknologi MARA, Selangor, Malaysia.
}

Revised: 30 September 2016; Accepted: 17 November 2016

\begin{abstract}
The purpose of this study was to investigate the ability of Acinetobacter sp. strain AQ5NOL 1 immobilised in gellan gum beads to degrade phenol in the presence of heavy metals. Seven different heavy metals, namely, $\mathrm{As}^{5+}, \mathrm{Cu}^{2+}, \mathrm{Cd}^{2+}$, $\mathrm{Ni}^{2+}, \mathrm{Cr}^{6+}, \mathrm{Pb}^{2+}$, and $\mathrm{Hg}^{2+}$ at 1 ppm were tested. Results of the study showed that degradation of phenol by free cells was inhibited by $\mathrm{Hg}^{2+}, \mathrm{Cu}^{2+}$ and $\mathrm{Cr}^{6+}$ after 48 hours of incubation by $97.91 \%, 77.58 \%$ and $75.26 \%$, respectively. Only $\mathrm{Hg}^{2+}$ and $\mathrm{Cr}^{6+}$ inhibited phenol degradation by immobilised Acinetobacter cells in 18 hours by $67.55 \%$ and $53.19 \%$. Phenol degradation by immobilised cells was affected when $\mathrm{Cr}^{6+}$ and $\mathrm{Hg}^{2+}$ concentrations exceeded 0.5 and $0.1 \mathrm{ppm}$, respectively. However, inhibitory effects of heavy metals can be overcome by prolonging the incubation time for immobilised Acinetobacter sp. strain AQ5NOL 1 from 18 hours to 24 and 30 hours for $\mathrm{Cr}^{6+}(46.80 \%)$ and $\mathrm{Hg}^{2+}(21.40 \%)$, respectively.
\end{abstract}

Keywords: Acinetobacter sp., biodegradation, heavy metals, immobilised cells.

\section{INTRODUCTION}

Heavy metals can be toxic to microorganisms even at low concentrations but several microorganisms have been shown to have an exceptional ability to adapt and colonise noxious metal-polluted environments (Yusuf et al., 2016). Certain bacteria have developed capabilities to protect themselves from heavy metal toxicity by various mechanisms (Shukor et al., 2010; Halmi et al., 2013; Karamba et al., 2015). Bioremediation is effective in degrading pollutants and thus able to get rid of unwanted substances from industrial wastes such as phenolic compounds, dye, crude oil and hydrocarbons
(Suhaila et al., 2013; Ahmad et al., 2014; Chander et al., 2014; Azri et al., 2015).

In a previous study (Ahmad et al., 2011; 2012), it was reported that Acinetobacter sp. strain AQ5NOL 1 utilised phenol as the sole carbon source with optimum temperatures ranging between 25 to $35{ }^{\circ} \mathrm{C}$. It has the ability to degrade $100 \%$ phenol up to $1100 \mathrm{mg} / \mathrm{L}$ and $1900 \mathrm{mg} / \mathrm{L}$ by free and immobilised cells, respectively in 10 days. As both heavy metals and phenol are harmful pollutants and often occur together, this study was carried out to determine the effects of selected heavy metals on phenol degradation by the bacterium Acinetobacter sp.. This investigation would be significant in designing effective bioremediation strategies.

\section{METHODOLOGY}

\section{Chemicals}

All chemicals used were of analytical grade and purchased either from Merck (Germany) or Sigma (USA).

\section{Microorganism and culture condition}

The phenol-degrading Acinetobacter sp. strain AQ5NOL 1 used in this study was isolated in Malaysia by Ahmad et al. (2011) as previously described. The bacterium was cultured in mineral salt medium (MSM) containing $(\mathrm{g} / \mathrm{L}): \mathrm{K}_{2} \mathrm{HPO}_{4}, 0.4 ; \mathrm{KH}_{2} \mathrm{PO}_{4}, 0.2 ; \mathrm{NaCl}, 0.1$; $\mathrm{MgSO}_{4}, 0.1 ; \mathrm{MnSO}_{4} \cdot \mathrm{H}_{2} \mathrm{O}, 0.01 ; \mathrm{Fe}_{2}\left(\mathrm{SO}_{4}\right) \cdot \mathrm{H}_{2} \mathrm{O}, 0.01$;

*Corresponding author (aqlima@upm.edu.my) 
$\mathrm{NaMoO}_{4} .2 \mathrm{H}_{2} \mathrm{O}, 0.01 ;\left(\mathrm{NH}_{4}\right)_{2} \mathrm{SO}_{4}, 0.4$ at $\mathrm{pH}$ 7.5. The MSM was supplemented with $0.5 \mathrm{~g} / \mathrm{L}$ phenol as the sole carbon source.

\section{Immobilised cells}

In this study, gellan gum gel was selected as the cell immobilisation matrix following the method described by Ahmad et al. (2012). A combination of $7.5 \%$ of gellan gum concentration, bead size of $3 \mathrm{~mm}$ diameter and bead number of 300 per $100 \mathrm{~mL}$ medium was used as the entrapment matrix. In this study, degradation of $0.5 \mathrm{~g} / \mathrm{L}$ phenol by free and immobilised cells $(3.5 \mathrm{~g} / \mathrm{L}$ of bacteria) was tested. Gellan gum beads without bacteria in MSM medium with phenol was used as the control. Phenol degradation was monitored by colourimetric assay for phenol using 4-aminoantipyrene as the reagent (APHA, 1998).

\section{The effects of heavy metals}

The effect of heavy metals on phenol degradation by the bacterium Acinetobacter sp. strain AQ5NOL 1 was determined using both free and immobilised cells. In this experiment, MSM containing $0.5 \mathrm{~g} / \mathrm{L}$ phenol was separately supplied with different heavy metals [arsenic $\left(\mathrm{As}^{5+}\right)$, chromium $\left(\mathrm{Cr}^{2+}\right)$, cadmium $\left(\mathrm{Cd}^{2+}\right)$, cuprum $\left(\mathrm{Cu}^{2+}\right)$, nickel $\left(\mathrm{Ni}^{2+}\right)$, lead $\left(\mathrm{Pb}^{2+}\right)$, and mercury $\left.\left(\mathrm{Hg}^{2+}\right)\right]$ each at $1 \mathrm{ppm}$ concentration. Bacterial cultures in free and immobilised cells $(3.5 \mathrm{~g} / \mathrm{L})$ were incubated in a rotary shaker at room temperature at $150 \mathrm{rpm}$. Based on this study (Figure 1), degradation of $0.5 \mathrm{~g} / \mathrm{L}$ phenol was analysed after incubation for $18 \mathrm{hrs}$ for immobilised cells and $48 \mathrm{hrs}$ for free cells, because these are the optimal incubation periods for $100 \%$ removal of phenol. Simultaneously, phenol degradation and bacterial growth were verified using 4-aminoantipyrene and colony forming units methods, respectively.

\section{Statistical analysis}

All experiments were carried out in triplicates. The data shown in the corresponding figures are the mean values of the experiment and expressed as mean \pm standard deviation (STDEV).

\section{RESULTS AND DISCUSSION}

Cell immobilisation is a promising approach in phenol biodegradation compared to free cells. In this study, immobilised Acinetobacter sp. strain AQ5NOL 1 in gellan gum beads showed faster phenol degradation than free cells at $0.5 \mathrm{~g} / \mathrm{L}$ of phenol (Figure 1). Complete degradation of phenol by free and immobilised cells occurred after 48 and 18 hours of incubation, respectively, while gellan gum beads without cells showed no phenol degradation. Gellan gum gel was selected as the immobilisation matrix based on its established superior characteristics compared to carrageenan, agar, and alginate (Sanderson et al., 1989; Nawawi et al., 2015; Yusuf et al., 2015).

Heavy metals affect phenol degradation by impeding bacterial growth and/or inhibiting enzymes that play major roles in phenol degradation (Nair et al., 2008; Arif et al., 2013; Norazah et al., 2015). Heavy metals directly affect the membrane structure by disturbing the electron transport chain (Hall, 2002; Russak et al., 2008). Freely-suspended cells are exposed directly to the heavy metals and easily react, thus slowing down the rate of degradation by disturbing the membrane structure. The effect of different heavy metals (1 ppm) on phenol biodegradation by freely-suspended and immobilised Acinetobacter sp. strain AQ5NOL 1 is given in Table 1. The results revealed that $\mathrm{Cr}^{6+}, \mathrm{Cd}^{2+}$, and $\mathrm{Hg}^{2+}$ inhibited phenol-degrading activity by inhibiting bacterial growth at 5.5, 5.3 and $0.0 \log _{10}(\mathrm{CFU})$, respectively compared to the control 8.2 $\log _{10}(\mathrm{CFU})(\mathrm{p}<0.05)$. However, this strain has been shown to have an exceptional ability to adapt and protect itself from $\mathrm{Cu}^{2+}, \mathrm{As}^{5+}, \mathrm{Ni}^{2+}$, and $\mathrm{Pb}^{2+}$ ( $\mathrm{p}>0.05)$ (Nawawi et al., 2015). $\mathrm{Hg}^{2+}$ gave the highest inhibition on phenol degradation with only $2.09 \%$ phenol degraded after 48 hours followed by $\mathrm{Cd}^{2+}(24.74 \%)$ and $\mathrm{Cr}^{6+}(22.42 \%)$. However with immobilised cells, only $\mathrm{Hg}^{2+}$ and $\mathrm{Cr}^{2+}$ inhibited phenol-degrading activities $(\mathrm{p}<0.05)$ up to $32.45 \%$ and $46.81 \%$ phenol being

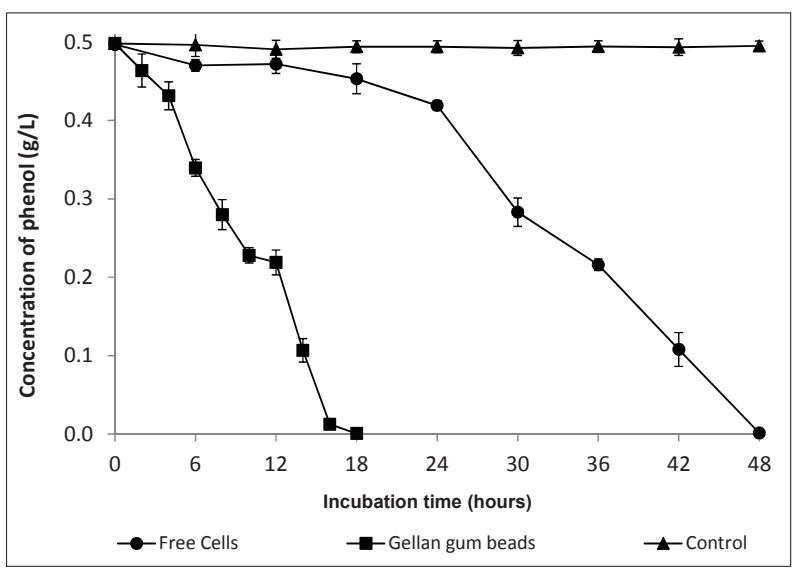

Figure 1: Degradation of phenol at $0.5 \mathrm{~g} / \mathrm{L}$ by free $(\bullet)$ and immobilised (ם) Acinetobacter sp. strain AQ5NOL 1. Gellan gum beads without the presence of bacteria were used as control ( $\mathbf{\Delta})$. 
degraded, respectively after 18 hours. Immobilised cells displayed better phenol degrading efficiencies than freely suspended cells after 18 hours. The immobilised cells were protected by the polymeric gel and less exposed to heavy metals, thus reducing the chance of heavy metals interrupting the degradation process (Chung et al., 2003). The application of immobilised cells in bioremediation exhibits many advantages over free cells, including the stability of active cells, recovery of cells, and reusability of the immobilised system (Yun et al., 2009; Ahmad et al.,

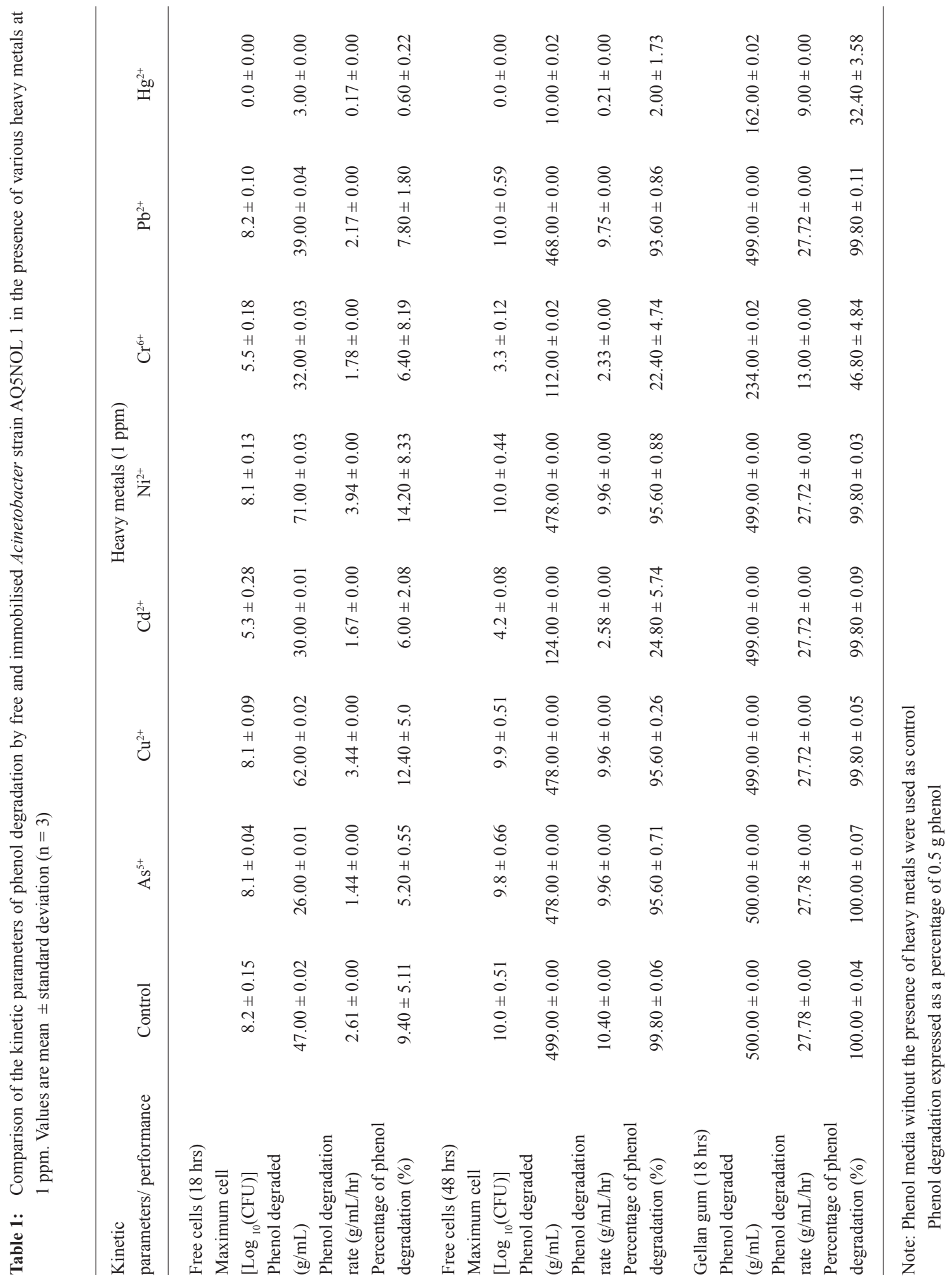


2012). Since $\mathrm{Cr}^{6+}$ and $\mathrm{Hg}^{2+}$ inhibited phenol-degrading activities of immobilised cells, investigations were carried out to find the effect of different concentrations of $\mathrm{Cr}^{6+}$ and $\mathrm{Hg}^{2+}$ (0.1 to $\left.1.0 \mathrm{ppm}\right)$ on phenol degradation after 18 hours.

In this experiment, at all concentrations studied, a lag phase was observed at the beginning before phenol degradation was observed (Figure 2). The completion of phenol degradation at 0.6 and $0.7 \mathrm{ppm} \mathrm{Cr}^{6+}$ concentrations occurred at 20 and 22 hours, respectively. At $0.8,0.9$ and $1.0 \mathrm{ppm}$ concentrations complete degradation occurred at 24 hours. The results indicate that immobilisation of cells in gellan gum beads protected the Acinetobacter sp. strain AQ5NOL 1 from chromium toxicity, with higher concentrations requiring an additional incubation period for complete degradation. In this case, the incubation time needed to be increased from 18 to 24 hours. The presence of a lag phase indicates that cells were adjusting to the toxicity of chromium through metabolic adaptation before phenol-degrading metabolism started. Gellan gum offers protection to heavy metal toxicity through various ways (Yusuf et al., 2016). The gellan gum itself can adsorb some of the heavy metals, reducing the bioavailability of the toxic heavy metals (Nawawi et al., 2015; Ibrahim et al., 2016). In addition, cells on the outer layer exposed to heavy metals adsorb the heavy metals, and become a protective layer to cells immobilised deep in the matrix (Ahmad et al., 2012). A summary of the phenol degradation kinetics is shown in Table 2.

$\mathrm{Cr}^{6+}$ is a unique transition metal ion, which has been established to be biologically significant on living organisms at all levels. However, at high concentrations, it inhibits the biodegradation of organic pollutants (Kourtev et al., 2006; Al-baldawi et al., 2015) including phenol (Al-Defiary \& Reddy, 2014). In the environment, pollution due to $\mathrm{Cr}^{6+}$ and its compounds is widespread because of their application in industry as dyes, pigments, and refractory material (Zakaria et al., 2012). It appears that this source of pollution is the same as phenol pollution. Additionally, chemical pollution due to phenol and $\mathrm{Cr}^{2+}$ in the ocean has been increasing in recent years in the China Sea (Zhang et al., 2007). According to a previous study, $\mathrm{Cr}^{2+}$ is more toxic on Gram-negative bacteria than Gram-positive bacteria at 1 ppm (Ross et al., 1981) and the toxicty of chromium to Acinetobacter sp. strain AQ5NOL 1, a Gram negative bacterium utilised in this study affirms this observation.

$\mathrm{Hg}^{2+}$ is considered the most toxic non-radioactive metal in the environment and is toxic in any form

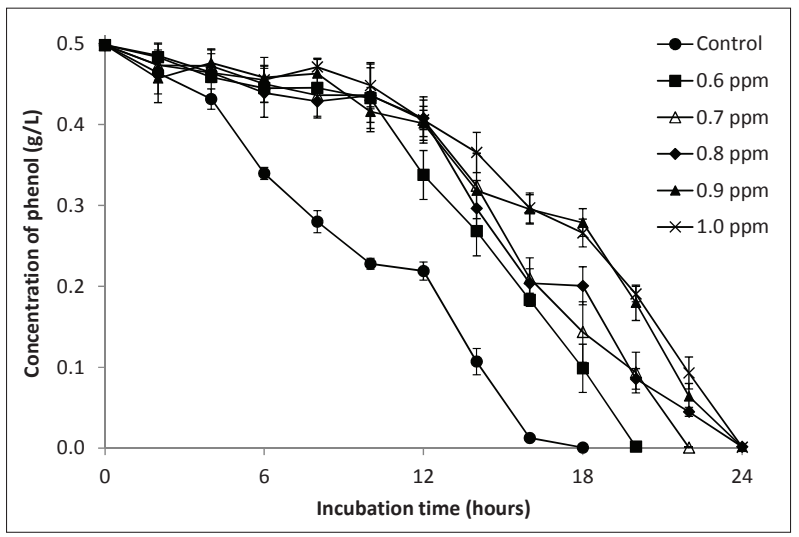

Figure 2: The effect of 0.6 to $1.0 \mathrm{ppm}$ of chromium on phenol biodegradation by immobilised Acinetobacter sp. strain AQ5NOL 1

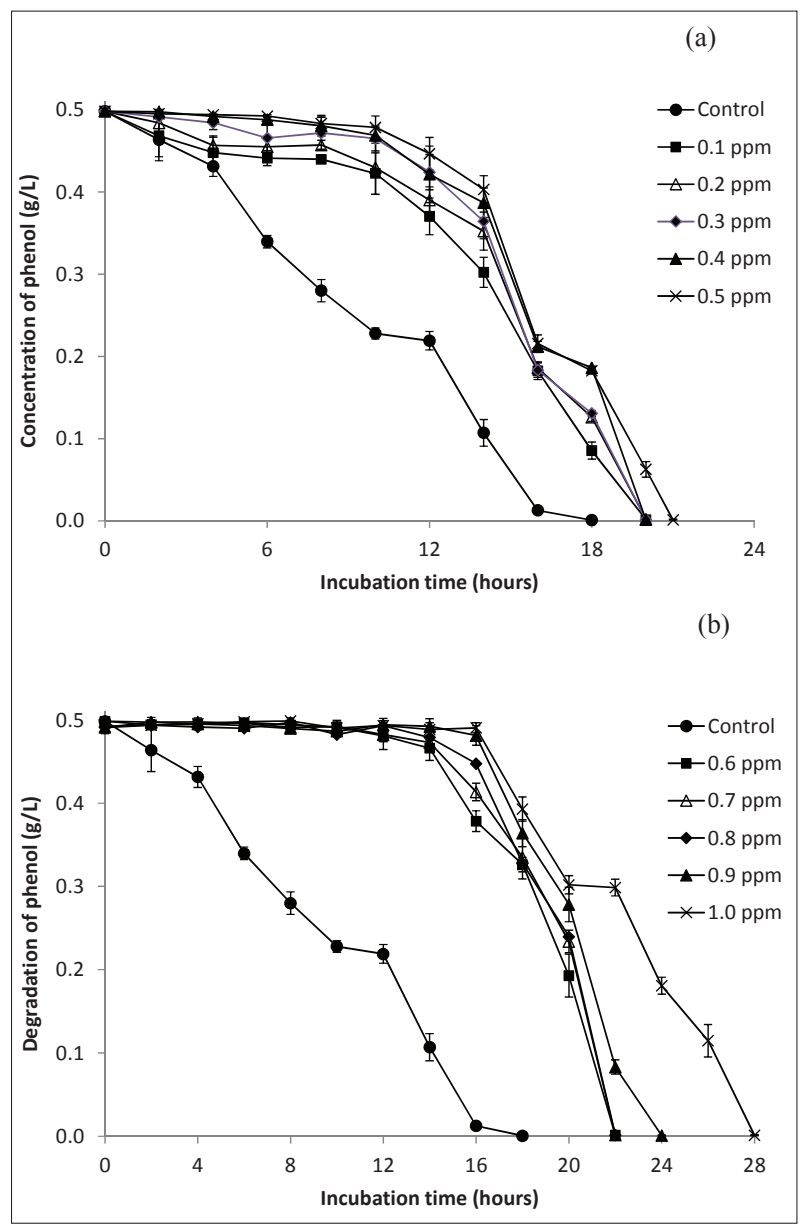

Figure 3: The effect of (a) 0.1 to $0.5 \mathrm{ppm}$ and (b) 0.6 to $1.0 \mathrm{ppm}$ of mercury on phenol biodegradation by immobilised Acinetobacter sp. strain AQ5NOL 1 


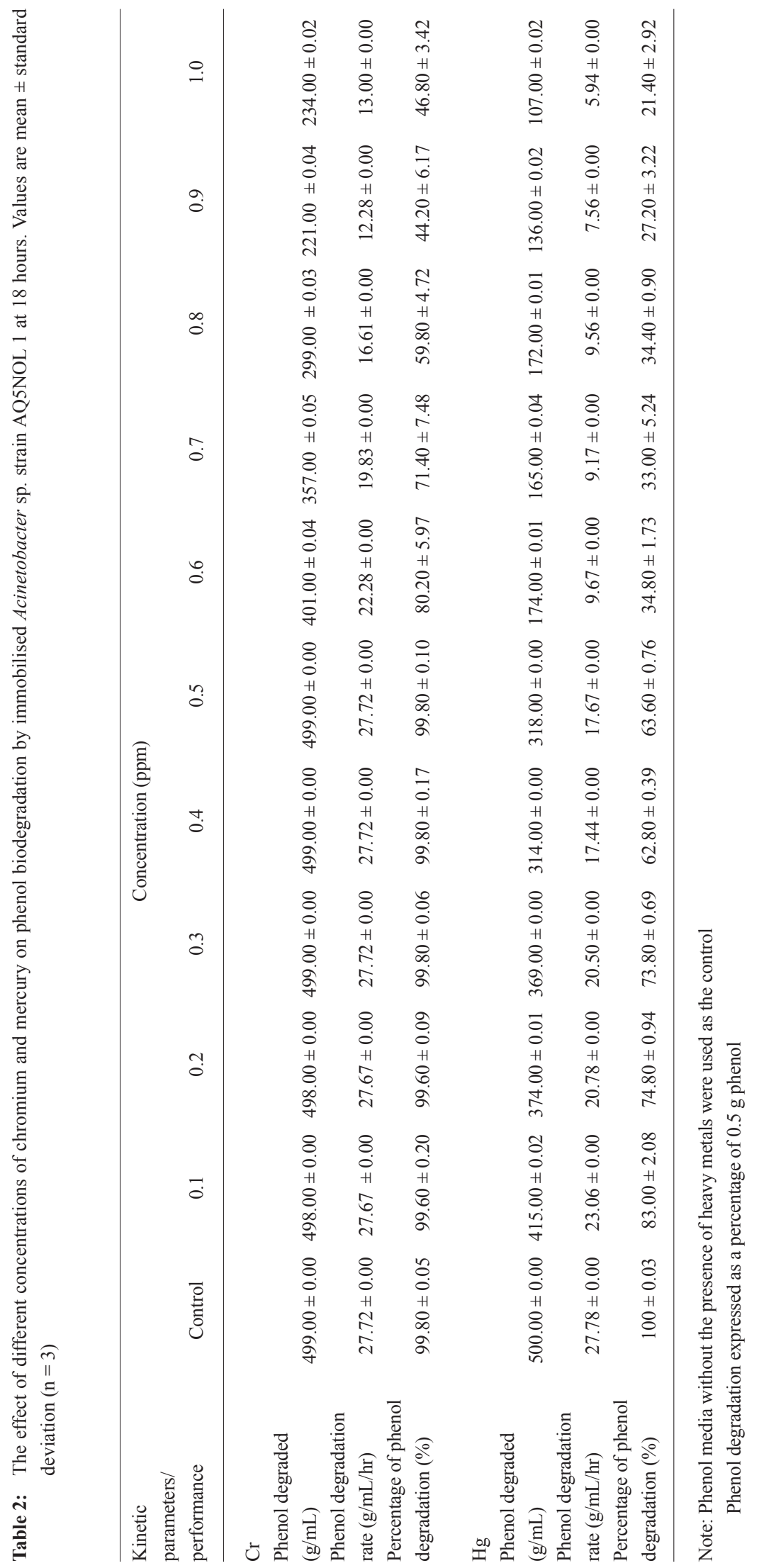


(Abdel-Salam et al., 2010). In Malaysia, the main sources of $\mathrm{Hg}^{2+}$ in river waters are urban and agricultural run-offs, effluent from industries, domestic discharges, sewage treatment plants, earthwork, constructions, and pig farms (DOE, 2002). This heavy metal also appears in phenol-polluted environments. Hence, the effect of $\mathrm{Hg}^{2+}$ on phenol degradation was studied. In this study, the presence of $1 \mathrm{ppm} \mathrm{Hg}^{2+}$ inhibited $100 \%$ of bacterial growth and phenol degradation by free cells, and more than $70 \%$ of phenol-degrading activities by immobilised cells. $\mathrm{Hg}^{2+}$ concentrations ranging from 0.1 to $1.0 \mathrm{ppm}$ affected phenol degradation $(\mathrm{p}<0.05)$ (Table 2). Above $0.5 \mathrm{ppm}$, the metal inhibited more than $60 \%$ of phenoldegrading activity, and this can be classified as very detrimental (Ahmad et al., 2015). But, the inhibitory effect can be overcome by prolonging the incubation time for immobilised Acinetobacter sp. strain AQ5NOL 1 from 18 to 28 hours (Figure 3). The inhibition of phenol degrading activities by 0.1 to $0.4 \mathrm{ppm}$ of $\mathrm{Hg}^{2+}$ was completed in 20 hours (Figure 3a), followed by $0.5 \mathrm{ppm}$ at 21 hours, 0.6 to $0.8 \mathrm{ppm}$ at 22 hours, $0.9 \mathrm{ppm}$ at 24 hours, and $1.0 \mathrm{ppm}$ at 28 hours (Figure $3 \mathrm{~b}$ ). In previous studies, $\mathrm{Hg}^{2+}$ has shown an inhibition of degradation of phenolic compounds by inhibiting hydroxylases activity such as 3-hydroxybenzoic acid-6-hydroxylase (Rajasekharan et al., 1990) and aryl 2,4-dichlorophenol hydroxylase (Radjendirane et al., 1991).

\section{CONCLUSION}

Gellan gum-immobilised Acinetobacter sp. strain AQ5NOL 1 provided excellent protection to the inhibitory effects of $1 \mathrm{ppm} \mathrm{As}, \mathrm{Cu}, \mathrm{Cd}, \mathrm{Ni}, \mathrm{Cr}, \mathrm{Pb}$ and $\mathrm{Hg}$ on the growth of the bacterium and the degradation of phenol by this bacterium. The inhibitory effects of chromium and mercury on immobilised cells could be overcome by prolonging the incubation period. The range of concentrations of heavy metals utilised in this study is very similar to the concentration range of heavy metals detected in the environment according to several studies and reports (Shukor et al., 2008; DOE, 2010). The results indicate that the immobilised bacterium utilised in this study can be an efficient candidate for phenol bioremediation in sites co-contaminated with heavy metals.

\section{Acknowledgement}

This work was supported by the Research Grants Scheme (RUGS) 2009, Universiti Putra Malaysia (91851).

\section{REFERENCES}

1. Abdel-Salam A.M., Al-Dekheil A., Babkr A., Farahna M. \& Mousa H.M. (2010). High fiber probiotic fermented mare's milk reduces the toxic effects of mercury in rats. North American Journal of Medical Sciences 2(12): 569 575.

2. Ahmad S.A., Ku Ahamad K.N.E., Wan Johari W.L., Halmi M.I.E., Shukor M.Y. \& Yusof M.T. (2014). Kinetics of diesel degradation by an acrylamide-degrading bacterium. Rendiconti Lincei 25(4): 505 - 512.

DOI: https://doi.org/10.1007/s12210-014-0344-7

3. Ahmad S.A., Shamaan N.A., Arif N.M., Shukor M.Y.A. \& Syed M.A. (2011). Identification and characterisation of a phenol degrading Acinetobacter sp. strain AQ5NOL 1. Australian Journal of Basic Applied Sciences 5(8): 1035 -1045 .

4. Ahmad S.A., Shamaan N.A., Arif N.M., Koon G.B., Shukor M.Y.A. \& Syed M.A. (2012). Enhanced phenol degradation by immobilised Acinetobacter sp. strain AQ5NOL 1. World Journal of Microbiology and Biotechnology 28(1): 347 352.

DOI: https://doi.org/10.1007/s11274-011-0826-Z

5. Ahmad S.A., Shukor M.Y., Shamaan N.A., Ab Rahman N.A., Dahalan F.A., Khalil K.A. \& Syed M.A. (2015). Effects of pesticides and respiratory inhibitors on phenol degradation by Acinetobacter sp. strain AQ5NOL 1 immobilised in gellan gum. Journal of Pure and Applied Microbiology 9: 489 - 495.

6. Al-Baldawi I.A.W., Abdullah S.R.S., Suja F., Anuar N. \& Idris M. (2015). Phytoremediation of contaminated ground water using Typha angustifolia. Water Practice and Technology 10: 616 - 624 .

DOI: https://doi.org/10.2166/wpt.2015.072

7. Al-Defiery M.E.J. \& Reddy G. (2014). Influence of metal ions concentration on phenol degradation by Rhodococcus pyridinivorans GM3. Mesopotamia Environmental Journal 1(1): $30-38$.

8. American Public Health Association (APHA) (1998). Standard Methods for the Examination of Water and Wastewater, 20 ${ }^{\text {th }}$ edition. American Public Health Association, Washington DC, USA.

9. Arif N.M., Ahmad S.A., Syed M.A. \& Shukor M.Y. (2013). Isolation and characterisation of a phenol-degrading Rhodococcus sp. strain AQ5NOL 2 KCTC 11961BP. Journal of Basic Microbiology 53(1): 9 - 19 . DOI: https://doi.org/10.1002/jobm.201100120

10. Azri M.F.D.B., Zulkharnain A.B., Husaini A.A.S.A. \& Ahmad S.A.B. (2015). The degradation of carbazole and the production of ligninolytic enzyme by isolated marine fungi. Journal of Chemical and Pharmaceutical Sciences 8(2): $330-335$.

11. Chander M., Singh D. \& Kaur R. (2014). Biodecolourisation of reactive red an industrial dye by Phlebia spp. Journal of Environmental Biology 35(6): 1031 - 1036.

12. Chung T.P., Tseng H.Y. \& Juang R.S. (2003). Mass transfer 
effect and intermediate detection for phenol degradation in immobilised Pseudomonas putida systems. Process Biochemistry 38: 1497 - 1507.

13. Department of Environment (DOE) (2002). Malaysia Environmental Quality Report 2002. Publication Section Strategic Communication Division, Department of Environment, Ministry of Natural Resources and Environment Malaysia, Malaysia.

14. Department of Environment (DOE) (2010). Malaysia Environmental Quality Report 2010. Publication Section Strategic Communication Division, Department of Environment, Ministry of Natural Resources and Environment Malaysia, Malaysia.

15. Hall J.L. (2002). Cellular mechanisms for heavy metal detoxification and tolerance. Journal of Experimental Botany 53(366): 1 - 11. DOI: https://doi.org/10.1093/jxb/53.366.1

16. Halmi M.I.E., Zuhainis S.W., Yusof M.T., Shaharuddin N.A., Helmi W., Shukor Y., Syed M.A. \& Ahmad S.A. (2013). Hexavalent molybdenum reduction to Moblue by a sodium-dodecyl-sulfate-degrading Klebsiella oxytoca strain dry 14. BioMed Research International 2013: 384541.

DOI: https://doi.org/10.1155/2013/384541

17. Ibrahim S., Shukor M.Y., Syed M.A., Johari W.L.W., Shamaan N.A., Sabullah M.K. \& Ahmad S.A. (2016). Enhanced caffeine degradation by immobilised cells of Leifsonia sp. strain SIU. Journal of General and Applied Microbiology 62(1): 18 - 24.

DOI: https://doi.org/10.2323/jgam.62.18

18. Karamba K.I., Shukor M.Y., Syed M.A., Zulkharnain A., Yasid N.A., Khalid K.A. \& Ahmad S.A. (2015). Isolation, screening and characterisation of cyanide-degrading Serratia marcescens strain aq07. Journal of Chemical and Pharmaceutical Sciences 8(2): 401 - 406.

19. Kourtev P.S., Nakatsu C.H. \& Konopka A. (2006). Responses of the anaerobic bacterial community to addition of organic C in chromium(VI)- and iron(III)-amended microcosms. Applied and Environmental Microbiology 72(1): $628-637$.

DOI: https://doi.org/10.1128/AEM.72.1.628-637.2006

20. Nair C.I., Jayachandran K. \& Shashidhar S. (2008). Biodegradation of phenol. African Journal of Biotechnology 7(25): $4951-4958$.

21. Nawawi N.M., Ahmad S.A., Shukor M.Y., Syed M.A. \& Ibrahim A.L. (2015). Immobilised Rhodococcal cells: a competent approach for phenol degradation by Rhodococcus sp. NAM 81. Journal of Pure and Applied Microbiology 9(2): $1301-1316$.

22. Norazah M.N., Jayasree N., Ahmad S.A., Shukor M.Y. \& Abdul Latif I. (2015). Disrupting Rhodococcus sp: a competent method for genomics and proteomics. Journal of Chemical and Pharmaceutical Sciences 8(2): 336 - 341.

23. Radjendirane V., Bhat M.A. \& Vaidyanathan C.S. (1991). Affinity purification and characterization of 2,4-dichlorophenol hydroxylase from Pseudomonas cepacia. Archives of Biochemistry and Biophysics 288(1): $169-176$.
24. Rajasekharan S., Rajasekharan R. \& Vaidyanathan C.S. (1990). Substrate-mediated purification and characterization of a 3-hydroxybenzoic acid-6-hydroxylase from Micrococcus. Archives of Biochemistry and Biophysics 278(1): $21-25$.

25. Ross D.S., Sjogren R.E. \& Bartlett R.J. (1981). Behavior of chromium in soils: IV. toxicity to microorganisms. Journal of Environmental Quality 10: 145 - 148.

26. Russak M.J., Kabala K., Burzynski M. \& Klobus G. (2008). Response of plasma membrane $\mathrm{H}^{+}$-ATPase to heavy metal stress in Cucumis sativus roots. Journal of Experimental Botany 59(13): $3721-3728$.

DOI: https://doi.org/10.1093/jxb/ern219

27. Sanderson G.R., Bell V.L. \& Ortege D. (1989). A comparison of gellan gum, agar, k-carrageenan and alginate. Cereal Foods World 34: 991 - 998.

28. Shukor M.Y., Ahmad S.A., Nadzir M.M.M., Abdullah M.P., Shamaan N.A. \& Syed M.A. (2010). Molybdenum reduction by Pseudomonas sp. strain DRY2. Journal of Applied Microbiology 108(6): 2050 - 2058.

29. Shukor M.Y., Masdor N., Baharom N.A., Jamal J.A., Abdullah M.P.A., Shamaan N.A. \& Syed M.A. (2008). An inhibitive determination method for heavy metals using bromelain, a cysteine protease. Applied Biochemistry and Biotechnology 144: 283 - 291.

DOI: https://doi.org/10.1007/s12010-007-8063-5

30. Suhaila Y.N., Rosfarizan M., Ahmad S.A., Latif I.A. \& Ariff A.B. (2013). Nutrients and culture conditions requirements for the degradation of phenol by Rhodococcus UKMP-5M. Journal of Environmental Biology 34(3): 635 - 643.

31. Yun Q., Lin Z. \& Xin T. (2009). Cometabolism and immobilised degradation of monochlorobenzoate by Rhodococcus erythropolis. African Journal of Microbiology Research 3(9): $482-486$.

32. Yusuf I., Ahmad S.A., Phang L.Y., Syed M.A., Shamaan N.A., Khalil K.A., Dahalan F.A. \& Shukor M.Y. (2016). Keratinase production and biodegrdation of polluted secondary chicken wastes by a newly isolated multi heavy metal tolerant bacterium-Alcaligenes sp. AQ05-001. Journal of Environmental Management 183(1): 182 - 195. DOI: https://doi.org/10.1016/j.jenvman.2016.08.059

33. Yusuf I., Shukor M.Y., Syed M.A., Yee P.L., Shamaan N.A. \& Ahmad S.A. (2015). Investigation of keratinase activity and feather degradation ability of immobilised Bacillus sp. Khayat in the presence of heavy metals in a semi continuous fermentation. Journal of Chemical and Pharmaceutical Sciences 8(2): $342-347$.

34. Zakaria Z.A., Ahmad W.A., Zakaria Z., Razali F., Karim N.A., Sum M.M. \& Sidek M.S.M. (2012). Bacterial reduction of $\mathrm{Cr}(\mathrm{VI})$ at technical scale - the Malaysian experience. Applied Biochemistry and Biotechnology 167: $1641-1652$.

DOI: https://doi.org/10.1007/s12010-012-9608-9

35. Zhang J.P., Yan Y.W., Xie J.J., Wang Q. \& Chen Q.X. (2007). Inhibitory kinetics of phenol on the enzyme activity of $\beta-\mathrm{N}-$ acetyl-D-glucosaminidase from green crab (Scylla serrata). International Journal of Biological Macromolecules 40(2): $139-143$.

DOI: https://doi.org/10.1016/j.ijbiomac.2006.06.022 